ABSTRACT

From Candle Light to Contemporary Lighting Systems: How Lighting Technology Shapes Scenographic Practices In this article, I discuss the influence of stage lighting on the processes of scenic design and the functioning of performance space. There has been a huge advance in lighting technology with regard to their accessibility, usability, luminosity and costs during the past decades. Light can no longer be thought of as a necessity that can just be added to the performance. It has become one of its basic visua elements, directing and focusing the spectators gaze. The rhythm of changing lighting cues create a visual dramaturgy, which has turned visual design from solid constructrions to a score of temporal events. Today you seldom see a performance without any use of projections or digital videos. I begin with a quick historical survey on the adaptation of electric light in orde to exemplify the artistic significance of technological innovations. I move on to a more philosophical conversation about the metaphorical connotations of light as a basic component of the visual mise-en-scène. Then I return to the practices of contemporary theatre making and examine the contributions of the latest projection technology.

I suggest that stage lighting has developed from being a technical tool making the scenes visible into a sovereign artistic agency creating images on its own terms. Today's intermedial scenography can be seen as a parallel to the contemporary experience of our spatio-visual environment in everyday life, echoing the changes that happen in our ways of perceiving and conceptualizing the world.

Keywords: scenography, lighting, theatre, technology, design, visuality.

BIOGRAPHY

Laura Gröndahl currently works as a researcher at Tampere University, focusing on documentary theatre. She has previously acted as a professor of stage design (2006-13) and as a visiting lecturer at the Universities of Helsinki and Lapland and Theatre Academy. Before taking her doctoral degree in 2004, she graduated as a scenographer in 1985 and worked in several Finnish theatres for almost 20 years. She has mostly been interested in the scenographic practices of theatre making and how they can be connected to different modes of thinking and conceptualizing lived experiences. laurakgrondabl@gmail.com

\title{
From Candle Light to Contemporary Lighting Systems: How Lighting Technology Shapes Scenographic Practices
}

\section{LAURA GRÖNDAHL}

Choreographer and Her Lighting Designer, ${ }^{1}$ a but we cannot see a light-beam unless it is reflected two-minute long video by Tülay Schakir, shows from some material surface, be it only a dust particle a woman dancing on a treadmill. Another stony- in the air. This dialectic reciprocity associates easily faced woman stands in the background and after a with the relation between human perception and while she switches the fluorescent lights off with a the perceived world, which raises phenomenological tiny gesture. A red light beam illuminates the danc- questions as to how things appear and make meaner from one side and her figure hovers magically in ing to us. Then again, the interplay between the set the emptiness. The same movements appear now as and light is always conditioned by existing technolodramatic and powerfully expressive, until the light gy, resources, stage architecture, prevailing theatrical changes back and we see the dancer just training in conventions and individual artists. Throughout the a shabby gym, again. The lighting designer looks as history of stage lighting, philosophical and practical indifferent as previously. This short video clip was conjunctures intertwine in a most intriguing way. part of the exhibition Valovuosi (Light-year), which I will first give a short overview of the formarepresented the work of Finnish lighting designers tion of modern scenography in terms of lighting at the Theatre Museum in 2009. To me it crystalliz- technology and design practices, then move on to es the significance of lighting in contemporary thea- some theoretical discussions and end my article tre: it makes things visible or invisible; it directs the with some tentative conclusions about the contemfocus and defines the mood of watching.

Throughout history, realistic painters have known how to use light and shadow to create dramatic effects. Today, nobody knows this better than a lighting designer who builds on a long tradition of elaborate visual performances, phantasmagorias and ghostly effects. It has, however, taken a surprisingly long time for the artistic significance of light in theatre to be acknowledged. The tool of making the stage visible has ironically remained invisible to many. In this article I try to mend the gap, perhaps just a little, by mapping how the development of lighting technology has influenced the scenographic $^{2}$ ways of using and thinking of the stage.

Set and lighting designs always go hand in hand. The set can be made visible only by means of light. porary digitalized stage. Besides well-known historical examples I will focus on Finnish theatre - no only because it is the most familiar context to me, but also because Finland is one of the few countries where lighting design has been systematically developed and offered at university level for almost 30 years, and therefore has a significant artistic status alongside set and costume designs.

THE HISTORICAL DEVELOPMENT OF MODERN STAGE LIGHTING:WHAT CAN YOU DO BY MEANS OF LIGHT?

Artificial lighting became necessary when performances moved indoors in the late sixteenth century. Although the scenographers of the past were 
amazingly inventive, technical means seem to have lagged behind artistic insights and endeavours until the present day. For example Philippe Loutherbourgh, who worked with David Garrick in Drury Lane, London 1771-85, and whom Scott Palmer credits as the first modern scenographer ${ }^{3}$ understood well the dramaturgical importance of lighting as a key tool for creating a realistic atmosphere and highlighting the effects of painted sets. We can only imagine his frustration with candles, torches and oil lamps when he and Garrick tried to darken the auditorium, illuminate actors with overhead lights and move the scenes further back on stage in order to create an illusory tableau. ${ }^{4}$ The only place where the actors' faces could be sufficiently lit was the forestage close to the footlights, and, interestingly enough, their visibility was considered as vital for their audibility, too. ${ }^{5}$ Moreover, the actors could not move too close to the painted scenes without ruining the visual illusion. Therefore the set was treated as a detached background rather than a functional environment for action, except in some special effects like flying scenes. Together with the wing change machines, the lighting conditions of the baroque theatre determined a rigid spatial order which prevailed, apart from minor changes, practically intact from the seventeenth to the late nineteenth century.

Things started to change slowly after the invention of gaslight, which was adapted to theatre purposes for the first time ca. $1816 .{ }^{6}$ Together with the limelight (1826) and carbon-arch (1846) it provided the first advanced toolkit for lighting the stage, enabling new operations: the light-beams could be focused, directed, shaped and coloured better than ever before. Luminosity increased significantly, which made it possible to focus on aesthetic issues besides sheer visibility. ${ }^{7}$ The electric light, which rapidly became common for fire safety reasons, completed this development in the late nineteenth century and beyond. Spotlights could be placed more freely in different positions on stage when there was no open flame. Light could be used as a dramaturgical tool once individual light sources could be regulated and controlled precisely by one man operating with a switchboard from one central position.
The invention of electric light had dramatic consequences to the set design. The actors became free to move on stage without disappearing into shadows. Painted backdrops lost their magic in bright light, and were soon replaced by three-dimensional sets, genuine furniture and real objects. The actors could then seize the props, slam the doors or climb on the set elements. Most modern theatre theorist like Stanislavski, Meyerhold and Brecht called for a new kind of designer who would be an architect and a constructor rather than a painter. The designer should be involved with the dramatic action, anticipating and suggesting possibilities of using the space and movement there, which makes scenography an inherent part of the particular mise-en-scèn of a play. Consequently, the set designer became a close partner of the director, stepping out from his studio to rehearsal rooms, discussing the contents of the play and developing the holistic visual score.

Nevertheless, previous conventions persisted in mainstream practices. As late as 1902 the Finnish National Theatre purchased painted backdrops - so called type-coulisses - from the atelier Grabow in Stockholm, and they were used alongside of othe sets until the 1930s. ${ }^{9}$ A telling detail is that when I studied scenography in Helsinki in the early 1980s, I still had to be trained in old-fashioned backdrop painting - although I never properly learned it. The long-lived, pictorial tradition has influenced the professional identity and teaching of scenography far into the modernist era by constituting it as a primarily visual art rather than a dynamic part of a performance. Although the pictorial scenerie were largely critized by modern theatre makers, they paradoxically had afforded a certain artistic autonomy to the set designer as a painter. Since the type-coulisses had not been tied to particular plays, the painters could cultivate their skills and talent more or less independently of the dramaturgical demands of the text, or the wishes of individual actors and directors. When the importance of scenography in the performance grew, the designer lost some of this sovereignty, because s/he had to adapt to the holistic mise-en-scène.

The integration of stage design and direction generated a persistant schism between actor-centre and visual theatre that seems to have penetrated dis- cussions on modern scenography throughout the twentieth century. It was expressed, for example, in Edward Gordon Craig's idea about Übermarionet ten, ${ }^{I O}$ or in Oskar Schlemmer's claim that the literal "sound stage", the actor's "play stage" and the designer's "visual stage" were separate dimension that could not be successfully combined in a performance unless one ruled over the others. ${ }^{11}$ The discrepancy between purely visual and narrative aims shows in the practical function of lighting, which always balances between the instrumental task of illuminating the scenes, and the expressive potentiality of scenography. For instance, a front light, which properly illuminates the actors' faces, often flattens the stage space, while visually impressive sceneries may leave the performers in shadow. This is probably one reason why so many avant-garde scenographies have been made in the context of modern dance. A dancer uses his/her whole body as a plastic figure, which can be lit as a dynamic part of the holistic scenery, whereas the drama actors' facial expression is crucial for their performance and necessitates front light in order to be perfectly seen.

Another important contribution of electric lighting was that it eventually made complete darkness possible. It enabled sudden blackouts, dramatic shadows, instant set changes and movie-like cuts from one scene to another on stage, which created a suggestive visual dramaturgy. This promoted a new, immersive mode of reception, which responded to the needs of the romantic-realistic bourgeois theatre. The lighting focused the spectator's complete attention on the onstage fiction, and allured him/her to forget the actual environment of the theatre and the fellow audience-members. The scenographer could start thinking of the stage as if it were a three-dimensional painting, an illusory window to another reality; or as a mouldable substance in which the vision could be sculpted by means of light. The scenographer Robert Edmond Jones wrote aptly in 1941: "We reveal the drama. We use light as we use words, to elucidate ideas and emotions. Light becomes a tool, an instrument of expression, like a paintbrush, or a sculptor's chisel, or a phrase of music."12 According to the longtime professor of lighting design, Markku Uimonen lighting is a process that require thinking, communicative interaction, research and dramaturgical understanding that exceeds technical and purely aesthetic needs. ${ }^{1}$

Nevertheless, the artistic potentials and technical needs of stage lighting were only slowly recognized in mainstream practices. For instance, traditiona theatre architecture did not provide suitable places from which the lights could be operated during the show. The switchboard was usually placed in the wings or under the stage where the electrician could not see the performance. The Finnish National Theatre had it moved to the back of the auditorium of the big stage as late as $1959 .{ }^{14}$ It took even much longer before lighting design was understood as a sovereign artistic occupation on its own terms. The birth of a specialized, self-conscious lighting designer dates back to the 1980s in Finland, which probably is the international average. However, lighting had become a major component of stage design much earlier. Scott Palmer notes that lighting technology started to change the production system of performances already in the late 1800s: "The increasing complexity of the lighting meant that the scenes now needed to be planned in advance and cue sheets developed so that the lighting could be repeated accurately in each performance."15

Because of the dramaturgical function of lighting cues, the whole scenography had to be though of in temporal terms and not as a purely spatio-visual, solid environment. It was not enough anymore to design the architectural structures and visual atmospheres; you had to think of it as a dynamic

Ville Toikka, the present lighting designer at the Finnish National Theatre, puts it beautifully: "Lights have the same function as the camera has in films: they focus and create the rhythm and atmosphere. The lights move things along and are thu part of the storytelling. Lights can open the stage up or decrease the size of the image and make people look at different parts of the stage; you can decide what it is that people will focus on and most of all what will go unnoticed. It is the job of the lighting designer to create a visual dramaturgy for the play." ${ }^{16}$ 
STAGE SPACE AND LIGHTING AS A PHILOSOPHICAL PERFORMANCE MACHINE Edward Gordon Craig and Adolphe Appia were probably the first and most famous theatre thinkers who fully understood the artistic potential of stage lighting. They both made roughly the same conclusions in the early 1900s: the stage must consist of simple, abstract elements, whose looks can be varied by means of light. Rejecting naturalistic sceneries, which represented the particular milieus of single plays, they strived for a kind of universalized stage, capable of hosting any single performance. According to Christopher Baugh, the essential question for Appia and Craig was the creation of scenery that "looks like nothing but itself". ${ }^{17}$ In other words, the set was not supposed to refer to any particular fiction or meaning but to stand for the internal structure and operational principle of theatre itself. The abstract stage is thus a platform, where the performance can emerge, or, as Baugh suggest in his phenomenal reading on 20th century scenographic technology: "The metaphor of the scene as a machine - as a physical construct that theatrically locates and enables the public act of performance - represents one of the earliest, and has proved to be one of the most long-lived, leitmotifs of scenographic research and experiment during the twentieth century. There is a significant parallel between the radical scientific enquiry into the innermost operation of all matter by clearing away surface texture and detail, and the discarding of all attempts at a scenic illusion in order to examine the inner mechanics of the place of performance."18

If the scenography is like a machine, what does it actually produce? One answer might be that it creates experiences in the spectators' mind by facilitating the performance event. In other words, it is a communication machine that transmits perceptions, emotions, thoughts and ideas. The operational principles of the stage are not only connected to physics, as Baugh notes, but also to the operationa principles of the human mind. A philosophical layer is thus present there, not necessarily in the sense of sophisticated theories but as often pre-conscious modes of everyday reasoning, involved rather in habitual practices than in precisely articulated ideologies.
Light is definitely an important component of the "performance machine" but how does it contribute to the examination of "the inner mechanics of the place of performance"? 19 Philosophically speaking, light has generally had a strongly metaphorical role in the history of Western culture. In most religions it is a sign of holiness or divinity. One only has to think of words like 'enlightenment' or phrases like 'I see', meaning 'I understand', to realize how closely light and vision are linked to knowledge, reason and truth in our thought. Still, the epistemic role of sight is ambivalent. On the one hand it is considered as the primary human sense, receiving reliable information from ones surroundings; on the other hand the eye can be easily deceived, and Plato himself doomed the visible appearances as phony delusions. It is hard not to associate lighting effects with the shadows on the wall of Plato's cave.

According to Martin Jay, the concepts of light as optical rays, called lumen, and the actual experience of human sight, known as lux, were separated already in Antique philosophy. This dual characte has been present in later Western philosophical and scientific discussions of light and vision. ${ }^{20}$ Exemplifying in practical terms the antagonism between empiricism and rationalism, it echoes the modes of visual representations in arts. Jonathan Crary in turn distinguishes between Cartesian and subjective visions in his study on the techniques of observation in visual arts and science. While the former mode of vision was constituted as disembodied optical laws, the latter paid attention to the ways in which the human psycho-physiological apparatus could produce visual experiences and illusions. ${ }^{21}$ According to Crary, the subjective vision became dominant from the 1830s and beyond, which matches the nineteenth century development of romantic-realistic scenography as an illusory apparatus. There, ligh became a magnetising tool of generating and controlling the performance consciousness (the liminal state of mind, which enables you to immerse in the play-world without completely losing the sense of the here-and-now reality)

The modern light manager was a new, vital agent in the twentieth-century theatre, a kind of a superior eye that defined what was seen and how. From a practical viewpoint, the scenography-ma- chine consists of two interdependent components: the physical, tangible set and the immaterial light, which makes the set alive. The visual designer balances between these aspects, which generates a tension that might be compared to discussions about the relation between the perceiving human min and the material world.

It is both a tempting and doubtful enterprise to interpret historical and present scenic convention as incarnations of philosophical comprehensions. We can easily find examples where the old-time theatrical space seems to duplicate current beliefs about the structure of the universe, society and the place of human beings there. The medieval stage was a microcosm consisting of earth, heaven and hell. The mechanical scenic machinery of the baroque theatre displayed the rationalist worldview by changing wings with the same accuracy as the godly clockwork was believed to move the universe. The physical separation of actors from the background scenery reminds one of the Cartesian distinction between the thinking subject and his material surroundings.

The philosophical impact of modern lighting in theatre history is more complex. On the one hand, the three-dimensionality of the stage space broke the division between actors and their surroundings and placed the protagonist into a new, dynamic interaction with her environment. On the other hand, the sharp separation of a dark auditorium from the brightly lit stage strengthened the split between audience and performance. The isolated spectator, exposed to a visual narrative that takes place somewhere else, resembles the Cartesian subject sitting in its chamber. Nevertheless, the spectator mentally fuses with the illusion and is thus most intimately united with the performance world.

If light could be compared to the artist's camera, paintbrush or chisel, it would be an active agent capable of creating new visions. It could be comprehended as a reflection of otherwordly ideas; or it might as well be understood as a curious gaze that can activate the visual potentials of the set and unfold its narratives and meanings like a scientific tool..$^{22}$ If lighting would play an active role in scenography, the material set would then be like screen or canvas on which the picture appears; or stone, in which the sculpture is carved. In other words, it would be a kind of a platform, where visual forms and meanings appear - not completely unlike the Platonic idea of space as chöra: a receptacle that has no character of its own, but can serve as a matrix for any sensible qualities. ${ }^{23}$ In his philosophical history of place, Edward S. Casey suggest that the Platonic chora represents one of the two different ways of regarding place that have prevailed in Western philosophy since antiquity and are still operative at the level of common sense thinking. ${ }^{2}$ The other comprehension of space, which Casey calls proto-phenomenological, can be traced back to Aristotle emphasizing the inherent power of physical and perceivable places. ${ }^{25}$ If you follow the second path as a scenographer, you might give primacy to the lived environment in its multisensory materiality and end up in site-specific performances.

Although Casey's notion of space clearly reminds one of the above mentioned dual characte of light, suggested by Jay, or the Cartesian and subjective visions by Crary, I do not believe that there is a straight line from these philosophical ideas to scenographic practices. Lots of different factors influence the choices of floor-level scenographic strategies, such as: what we decide to illuminate in the first place, how do we construct an illusion, how a scene change is carried out, etc. Obviously there is always a limited selection of options defined by financial and technical circumstances, cultural and theatre-specific conventions and individual knowledge, skills and preferences. It is, however, possible to think that the practical negotiations between the available scenographic options and the desired outcomes embody a fundamental question, how something concrete and material (what there actually is on stage) turns into something abstract and mental in the artistic experience of a performance (how it is perceived, sensed and interpreted). The tension between set and light as 'the leading' visua component is significant in itself because it trigger phenomenological and epistemic contemplations by visualizing the dialectic between perception and the world perceived. Perhaps lighting today can be truly experienced as art on its own terms because of 
the presence of such discussions, which have come to the fore because of the technical advances that have given light a prominent role in practice.

\section{BACK TO THE GRASS-ROOT LEVEL OF LOCAL SCENOGRAPHIC PRACTICES}

As already mentioned, the position of lighting designers in theatre making was only slowly recognized in the professional practices. Although I, at the beginning of this article, praised Finland as a pioneering country with regard to the education of lighting designers, ${ }^{26}$ the conventional hierarchy of the artistic team did not change remarkably in the mainstream theatre until the new millennium. The usual practice by the 1990s was that the set designe and director developed the visual dramaturgy, and the electrician just operated the lights. ${ }^{27}$ The former mostly lacked the sufficient technical expertise and know-how of lighting, while the latter were hired and trained as technicians, lacking artistic education. This was not only a matter of skills or attitudes, but also due to a shortage of working hours. The lights were often set during the nights just before the last rehearsals, when everything else was more or less finished and there was no time to further adjustment. The electrician could only rarely join the brainstorming sessions or early rehearsals and could, therefore, not participate in the creative preplanning work with the set designer and director. S/ he ${ }^{28}$ just illuminated the ready-made performances.

According to this working model, lighting was still considered as an instrumental part of the overall set design and was subordinated to traditional methods, which had been developed to shape fixed, material elements. The set was - and still is - usually designed by means of scale models and drawings. While the material set and the spatial arrangement can be rather accurately demonstrated in a wellmade scale model, it is hard to simulate the light effects there. ${ }^{29}$ You can roughly suggest the main direction and shade of the lights, but not really experiment with different options, which have to be seen one-to-one on stage..$^{30}$ The recently developed computerized modelling programmes afford a remarkable help. ${ }^{31}$ They allow the set and lighting designers to work on the same virtual platform and simulate the scene sequences. Moving the set design from material scale models to 3D-modelling on the computer may, however, undermine the three-dimensionality of the space and lead to more pictorial sceneries, since the stage is depicted as a geometric projection instead of tangible particles. The physical model is also favoured as it allows all the team-members better access to joint planning with miniature set-elements.

Another factor is that the lighting cues are bound to the live performance action and you cannot decide on them until you know what is going to happen there. And that can only be properly known in live rehearsals. This is one of the many reason why, lately, young theatre makers have put the established production system of Finnish theatre at stake. The prevailing tradition is that a performance is made according to an accurate collaborative pre-planning process, which excludes the actor from the creative development of the stage structures and visual dramaturgy. The scenography is designed as a conceptual idea, generated before the rehearsals and just transplanted onto the stage. The present system takes good care of the visual dramaturgy of the play-narrative, but the unpredictable eventness of the live, bodily performance is largely forgotten.

Dissatisfaction with these pre-planning practices has been countered by different devising methods that are based on improvisation and non-hierarchical, self-regulating working processes. These are nothing new in theatre history and they have usually caused problems for the set designers, whose innovative ideas are inevitably decelerated by the slowness of material constructions. ${ }^{32}$ Contemporary lighting technology offers much more flexible tools, which is one reason why devised, process-based theatre often takes place on empty stages. A simple colour-wash can change the look of the scenery in some seconds, while it would take hours to pain the walls. A gobo imitating foliage can create a perfect illusion of a sunny garden in an empty space, and projected waves can turn a wooden platform into an open sea

Although the basic operational principles of stage lighting have not significantly changed since the early twentieth century, there has been a con- stant advance towards better luminosity, controllability and flexibility. Most of the development can be described as an accumulation of relatively small but important steps, which have turned into a notable qualitative leap around the turn of the millennium. Modern theatre houses with neutra black box stages have been optimally designed fo the needs of lighting. Lens technology, lamps, filter and dimming systems have improved rapidly; better rigging techniques, lighting bridges and grids have increased safety and reduced time-consuming practical work. ${ }^{33}$ Computerized switchboards, which became common during the 1980 s, helped significantly the recording and changing of complex lighting cues. The lighting designers Juha Westman and Ville Toikka summarized the most relevant lighting innovations by 2005 as follows: the growth of luminosity, remote controlled motorized spotlights, digitalized visual technology, better projectors and, above all, the devices have become more affordable, easily accessible and easier to use than before. ${ }^{3}$

All this means that light has become a truly viable and functional part of performances in average productions and as Westman put it: "There are enormous amounts of light on stage nowadays Sometimes I wonder, how people previously used to see anything at all." ${ }^{3}$

NEW TECHNOLOGY ON STAGE:WHAT HAPPENS NOW

The most intensively developed part of contemporary stage lighting is in the field of projector technology along with digital image-processing. It does not only mean that light can create new vision in interaction with the set, but it carries in itself a stream of autonomous images from different sources. Although the projected pictures technically only consist of coloured lights, they can be legitimately compared to the tradition of painted backdrops because they also present visual sceneries physicaly disconnected from the embodied actors and are highly dependent on technical and artistic expertise. However, contemporary technology allows completely different options for the performance, turning the whole stage into a multimedia performance where live and projected scenes merge. I have seen performances where live dancers and objects amatgamate with projected images so seamlessly that could not always see the difference. Nevertheless, a more frequent strategy is the interplay between physical presence and immaterial reflections, for instance by using digital videos on stage, often shooting scenes with a freehand camera and then showing them on screen in real-time, simoultaneously with the acting.

A typical example was The Year of a Rabbit, premiered on 10 October 2013 in Ryhmäteatteri, Helsinki. ${ }^{36}$ Almost half of the scenes were played out of sight behind a wooden wall on stage, where they were recorded and projected simultaneously on three screens, all duplicating the same image. The stagehand using the camera was clearly visible bu avoided drawing any attention to herself. Nevertheless, the stagehand Viivi Kuusimäki's vital role was acknowledged by mentioning her name on the handbill among the actors. She also came out with them for the curtain call, which stagehands, normally, do not do. The real-time videoed scenes were mostly monologues. The freehand, slightly vacillating camera followed the actors at a close distance, focusing on their faces or hands. The framing of the close-ups seemed rather accidental and fragmented, and sometimes the focus was lost for few seconds. On the one hand, the shots looked like an amateur home video, on the other hand, their style referre to a documentary camera, recording random events as they just happened.

The presence of the camera could be seen as a meta-theatrical gesture pointing at the mediated character of the performance, which also applies to the general conditions of modern life. On the most obvious level, there was a reference to contemporary reality-TV shows or to self-representations in socia media. On the level of story, it could be read as a sign for the ubiquity of the public gaze causing the protagonist's alienation from his inside feelings and desires. On the level of reception, the video reminded one that the stage picture is always positioned and constructed. The actual play-scene was mostly left unseen and you could not know what 'really' happened, since only the act of filming was directly 
visible. The mediation and communication process became an essential part of the performance, perhaps its actual subject.

Some ten or fifteen years ago The Year of a Rabbit would probably have been categorized as experimental, but today it is rather a typical example of mainstream theatre. The reviewers did not pay much attention to the projections. ${ }^{37}$ Those who mentioned them referred to their commonness and discussed their adequacy in this particular context, mostly in positive tones (one blog-writer was critical claiming that the videos were a substitute for the actors' work). It seems that the reviewers and blog-writers took the new visual technology as an established part of the stage-technological repertoire. In fact, projected images, even moving ones, are nothing new on stage even in a historical perspective. The basic optical laws guiding the reflections of light have been known for ages. What makes a difference today, is the advanced nature and accessibility of high-tech lighting sources and digitalized image processing. While early pioneers of visual stage technology like Erwin Piscator or Josef Svoboda created unparalled innovations and experiments in their own time, practically anybody can now purchase and use small-sized cameras that do

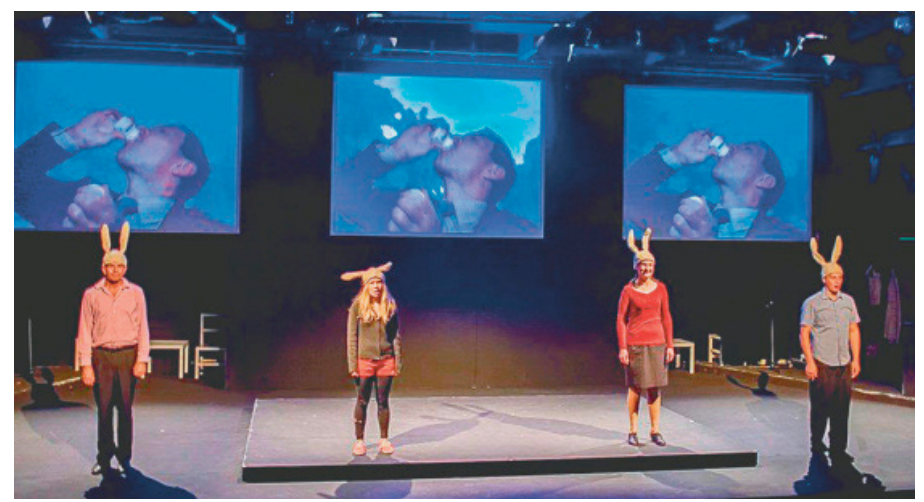

The Year of a Rabbit (2013), Ryhmäteatteri, directed by Esa Leskinen. Photo: Johannes Wilenius.

not need much light and projectors that can successfully reflect images on any surface.

In the literature about the cultural and historical influence of technology, the adaptation of new technical devices has often been described as a three-phase process: the invention, development and spread. ${ }^{38}$ At the end, the technology completely penetrates people's living conditions and they cannot do without it. In this phase, technology truly dominates culture because it becomes such a natural part of life that people cannot think of any alternatives to it. ${ }^{39}$ While this model may be too deterministic as such, it might shed some light on the development that is now happening with advanced theatre lighting and projection technology.

When a new technology enters our lives, it changes our ways of experiencing the environmen and makes us redefine our habitual practices, values and beliefs (just compare it to the difference in attitudes between teenagers and middle-aged people using computers and the Internet). Arnold Aronson has noted that we do not see the everyday world in the same way as our ancestors did in the early 1900 s, since we are used to artificial lighting and other visual technology in our lived environment. ${ }^{40}$ other visual technology in our lived environment.
Therefore, we can no longer light theatre as Appia

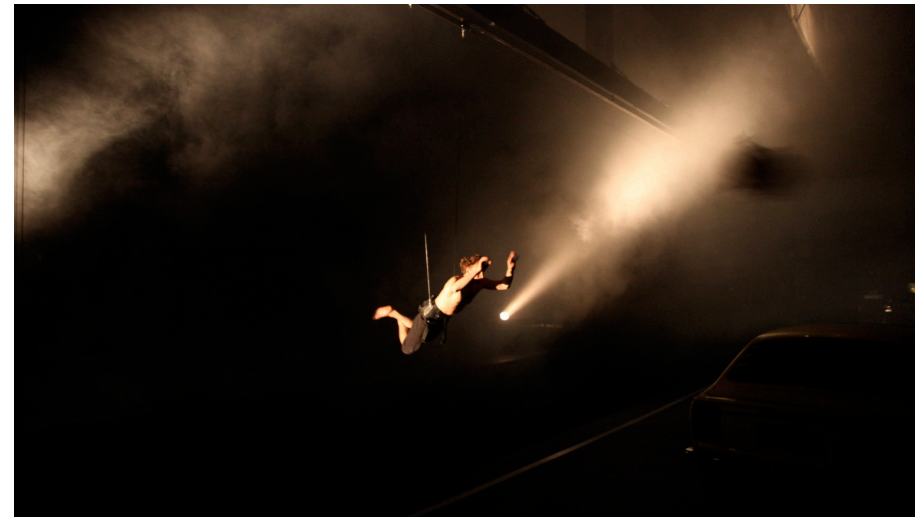

Lighting exercises from the Big Stage workshop arranged by the Theatre Academy, University of Tampere, the University of Industrial Arts and the Tampere Workers'Theatre in 2009. Photo: Kimmo Karjunen.

suggested: "The way in which we light the stage is indicative of how we see light in our daily lives." 4 Aronson refers not only to the lighting of our everyday environment but to the influence of all media technology that change our habitual ways of seeing.

However, in another essay he severly doubts that projection technology, films and videos could be successfully combined to live performances because theatre and (other) media speak fundamentally different languages. ${ }^{42}$ Then again, he ends the essay by crediting The Wooster Group for its use of videoes, which call into question our various ways of seeing and challenging the notion of theater in our times. ${ }^{4}$ Theatre has been characterized as a hypermedium that has always been able to assimilate other media into itself without annihilating their special character. ${ }^{44}$ The video on stage may be a narrative tool, but it also represents a video clip being displayed in the live performance. It is an intrusion of another logic of representation, which makes us aware of the existence of different modes of communication. This accentuates the meta-theatrical level of reception, examining the functioning and constitution of all media, including theatre. Although some of the current popularity of projection and video technology can be simply explained by the thrill of a new toy, us unrivaled tools for dealing with our changing modes of perception and communication in everyday life and culture.

\section{TOWARDS A VIRTUAL STAGE? SOME}

\section{CONCLUDING REMARKS}

The innovation of electric light revolutionized the artistic and technical practices of scenography one hundred years ago. Are we now witnessing a similar turn promoted by digitalization, or is it rather a completion of the previous processes? What happens to scenography as an occupation? Which artistic possibilities emerge and which disappear? How does recent projection and video technology rearrange the mutual hierarchy and interaction of set, light and actors?

From the perspective of scenography, the idea of light as the paintbrush of the designer seems to have I believe they have come to stay because they offer 
achieved its peak here. The physical set is reduced to an almost indistinguishable platform for shifting imagies, mediated through screens that open like wormholes to any places outside the stage space. The light does not illuminate something that exists in the space, but it creates new visions by borrowing and recycling digitalized images from any sources. Light has thus gained a new level of autonomy. Thinking in postmodern terms, this may imply an understanding that there is no essential or material substance to make visible on stage: there is no solid world to be lit and revealed; only reflections and utterances that produce the world we live in. The tool, which once was used for instrumental, purposes has become a performance of its own, a scene machine that endlessly produces and reproduces images and meanings.

Visual design in theatre now enjoys a freedom, similar to cinema, which can move the performance to any place on the earth in a fraction of a second. The real-time camera can be brought to any part of the theatre building and its surroundings; it can even be fixed to the bodies of moving actors. This expands the visible stage space, shows subjective viewpoints and hidden, secret corners. It also breaks the natural sense of spatial continuity, which is at odds with the notion of theatrical presence: the audience is simultaneously aware of their fixed physical location in the venue and the changing view from other places. Even if the success of such combinations is much debated and suspected, the inconsistency of simultaneous different spatial experiences is typical to our time in general. We spend an increasing part of our time in televisual spaces, which cannot be located in any physical place. For instance, where am I mentally, while talking with my friend through Skype while sitting in a train, racing $200 \mathrm{~km} / \mathrm{h}$ from one city to another? Is there not something similar to the fragmented digitalized stage? Is the combination of video and live performances emblematic for contemporary theatre exactly because it echoes our everyday experiences of mobility and spatial discontinuity; being connected to distant places while loosening the immediate contact to the nearest neighbourhood?

Projection technology puts a lot of requirements on the physical stage space. The screens and projec- tors have to be situated in precise places, which limits the spatial design of the performance. This further influences the actors' movements and the use of the set. If the videos play a major role, it easily lead to a pictoriality not completely unlike the painted backdrops: the spatial composition is rigid, and the visual scenery separated from the actors' space. However, contemporary performances often deliberately play with this distinction by accentuating the difference of bodily performers and the virtua screen. This elevates the gap between lived experience and mediated representations to the focus of interest. The stage can be described as dualistic, bu there emerges a kind of liminal interspace between the material bodies and immaterial images, which generates a phenomenological idea of encountering between inside and outside. Instead of a separation, there is rather a dialogue.

The actors can perform both as bodily beings on stage and as virtual duplications on screen. On the practical level this solves the already discussed dilemma of lighting: visually impressive scenes often leave the actors' faces and gestures in shadow. The close-up video can pick subtle facial expressions and the audience can see it simultaneously with the holistic visual scenery. The same thing happens auditorily with the use of personal microphones, which can make a whisper heard on the big stage. The actor's expression is 'divided' into discrete parts like the voice or face, which can be magnified, duplicated, distorted and used freely as part of the scenery. The intensity of the actor's speech and mime may thus vary much more, but $s /$ he is also released from his/her physical position on stage. This can be very problematic for the live performer if traditional contact to the audience and to the fellow actors is broken. The actor becomes rather a visual component: s/he is not only used as a figure that can be lit in many ways, $s /$ he is completely dissolved into sculptable material for scenic design. Then again the bodily actor can interact with his/her own real-time image, which generates an interesting feedback loop between two modes of performing. The dissolved and re-assembled actors remind one, of course, of postmodern identities, which are in a constant process of re-construction, captured in the rupture between presence and re-presentation.

\section{NOTES AND REFERENCES}

Tülay Schakir, "Choreographer and Her Lighting Designer", Nomadi productions, a video in Valovuosi variaatiota valosta, DVD-publication of the exhibition of light design at the Theatre Museum in 2004, Tarja Ervasti, ed., Helsinki 2009

2 I use the word 'scenography' to mean the whole visual and spatial framework of a performance. It includes the set, lights, costumes, masks, hairdos and sometimes even sounds. In this paper I focus only on the two first aspects: set and light. (Heta Reitala, Suomalaista skenografiaa: lähtökohtia tallennukseen, tutkimukseen ja historiaan Taideteollisen korkeakoulun julkaisusarja, Helsink 1986).

Scott Palmer, Light, Palgrave Macmillan, Hampshire and New York 2013, p. 63

Ibid., p. 61 and Christopher Baugh, Theatre, Performance and Technology. The Development of Scenography in the Twentieth Century, Palgrave Macmillan, Hampshire an New York 2005, pp. 14-15.

5 Ibid.

6 Baugh, op. cit., p. 173

Markku Uimonen, "Mehr Licht? Warum?" in Valovuosi variaatioita valosta, op. cit., p. 5 .

8 Joslin McKinney, Philip Butterworth, The Cambridge Introduction to Scenography, Cambridge University Press, Cambridge 2009; Baugh, op. cit.; Pamela Howard, What Is Scenography?, Routledge, London and New York 2002.

9 Pentri Paavolainen, Aino Kukkonen, Näyttämöllä. Teatteribistoriaa Suomesta, WSOY, Helsinki 2005, p. 82.

10 Edward Gordon Craig, "The Actor and the Über-marionette" in Theatre and Performance Design. A Reader In Scenography, Jane Collins, Andrew Nisbet, eds., Routledge, London and New York, pp. 257-63. (First published in On the Art of the Theatre, Heinemann, London 1911, pp. 80-94.

11 Oskar Schlemmer, "Man and Art Figure" in The Theate of the Bauhaus, Walter Gropius, Arthur S. Wensinger eds., Wesleyan University Press, Middletown, Connecticut 1961, pp.17-46.

12 Palmer, op. cit., p. 106

13 Uimonen, op. cit. pp. 5-7.

14 Ervasti, op. cit, p. 23.

15 Palmer, op. cit., p. 179

16 Laura Gröndahl, "The Lighting Designer Is the Bassist of the Stage" in Theatre People - People's Theatre, Kais Korhonen, Katri Tanskanen, eds., LIKE, Helsinki 2006, pp. 103-10.

17 Baugh. op. cit., p. 46.

18 Ibid., pp. 46-7.

19 Ibic

20 Martin Jay, Downcast Eyes. The Denigration of Vision in the Twentieth-Century French Thought, University of California Press, Berkeley, Los Angeles and London 1993. pp. $29,150$.

21 Jonathan Crary, Techniques of an Observer. On Vision and Modernity in the Nineteenth Century, The MIT Press, Cambridge, Massachusetts and London 1990; see also

22 See Jay, op. cit.

23 Edward S. Casey, The Fate of Place. A Philosophical Histo$r y$, University of California Press, Berkeley, Los Angeles. London 1998, pp. 32-3.

24 Ibid., p. 57

25 Ibid., pp. 50-71.

26 University-level courses in lighting design were established at the Theatre Academy in 1986, including BAMA- and doctoral degrees.

27 Interviews with Kati Lukka (16.2. and 28.4.2005), Ville Toikka (16.2.2005) and Juha Westman (28.4.2005), interviewer Laura Gröndahl, partly published in Theatre People - People's Theatre, op. cit. I have also used my own practical experience as a scenographer 1983-2001.

28 The lighting designers and electricians in Finnish theatres were exclusively male until the late 1980 s, when first women, e.g. Tarja Ervasti and Emma Paaer entered the field.

\section{Toikka, op. cit.}

30 Ibid.

31 Uimonen, op. cit., p. 6.

32 Discussions on the theme: Howard, op. cit.; Laura Gröndahl, "Mitä lavastuksen tekniikka sanoo?" i Näkyvää ja näkymätöntä. Näyttämö ja tutkimus, Laura Gröndahl, Anna Thuring, Teemu Paavolainen, eds. Suomen teatterintutkimuksen seuran vuosikirja, no. 3 , Helsinki 2009, pp. 91-115; Laura Gröndahl, "Ai siit tuli sitten tuollainen... Käytännön näkökulmia lavastusten syntyprosessiin" in ibid., pp. 149-171.

33 Palmer, op. cit., pp. 197-206.

34 Westman, op. cit.; Toikka, op. cit.

35 Westman, op. cit.

36 Jäniksen vuosi (The Year of a Rabbit), directed by Esa Leskinen, Ryhmäteatteri, Helsinki 2013.

37 E.g. Lauri Meri, "Ryhmäteatterin Jäniksen vuosi tarjoaa 
sekä keppiä että porkkanaa" in Helsingin Sanomat, 12 October 2013; Hannu Hurme, "Jäniksen vuosi - komediaa tosikkokaavalla" in Kansan Uutiset (e-version), 14 October 2013; Liisa Talvitie, "Jäniksen vuosi on entistă ajankohtaisempi" in $A p u, 11$ October 2013; Jukka Vuorio, "Rytinällä ulos oravanpyörästä" in Sylvi (e-version), 28 October 2013; Kimmo Jylhämö, "Jänistyttö vapauttaa miehen" in Voima, no. 9, 2013

38 E.g. Näkökulmia teknologiaan, Tarmo Lemola, ed. Gaudeamus, Helsinki 2000; Karl-Erik Michelsen "Teknologian historia - tutkimuksen unohdettu ulottuvuus" in Historia nyt, Pekka Ahtiainen et al., eds., WSOY, Helsinki 1990, pp. 151-9; Timo Airaksinen, Tekniikan suuret kertomukset, filosofinen raportti, Otava, Helsinki 2003; Hannu Salmi, Atoomipommilla kuuhun, tekniikan mentaalihistoriaa, Edita, Helsinki 1996.

39 Airaksinen, op. cit., p. 174

40 Arnold Aronson, "One Hundred Years of Stage Lighting" in Looking into the Abyss. Essays on Scenography, The University of Michigan Press, Ann Arbor 2005, pp. 2943.

41 Ibid., p. 30.

42 Arnold Aronson, "Can Theater and Media Speak the Same Language" in Looking into the Abyss. Essays on Scenography, op. cit., 86-96.

43 Ibid., p. 94 .

44 Intermediality in Theatre and Performance, Freda Chap ple, Chiel Kattenbelt, eds., Rodopi, Amsterdam, New York 2006. 